\title{
Development of Indonesian Language Teaching materials in Universities
}

\author{
Noni Febriana ${ }^{1)}$, Desi Afrianti ${ }^{2)}$ \\ ${ }^{1)}$ Universitas Putra Indonesia YPTK, ${ }^{2)}$ Universitas Putra Indonesia YPTK \\ email: NoniFebriana6@gmail.com ${ }^{1}$, desiafrianti86@gmail.com ${ }^{2}$
}

\begin{abstract}
This study aims to develop a valid and relevant teaching materials with Indonesian language course material. This study uses a Research and Development (R\&D) approach. The research subjects are lecturers and students. Data collection techniques in this study used observation, literature study, documentation, interviews, and assessment questionnaires. The stages in this research start from assessing potential and problems, collecting data, making product designs, validating product designs, revising products, and testing products. As a result, the textbooks developed were to support lectures and become a handbook for lecturers and students for academic purposes. The results and conclusions in this study, Indonesian language textbooks are good for college students to use. This teaching materials can also be used as a guide for lecturers in carrying out teaching and learning activities in universities.
\end{abstract}

Keywords: development, indonesian language learning, teching materials

\section{Introduction}

In higher education, Indonesian language is a general subject that is studied by almost all majors, therefore it is important for Indonesian language courses to have a handbook for students who are studying these subjects. Textbooks are very useful as learning resources for students directly and concretely because they can provide illustrations on something that is difficult to hold, visit or see directly. and the latest in full according to student characteristics (Timmerman, et al., 2008; Williamson, et al., 2006; Bednekoff, 2005). Good quality learning materials and standards will be able to help students in learning, so that competence can be achieved. Teaching materials can also help solve educational problems and provide positive information because they can lead students to think, behave, and develop further. Teaching materials are useful for developing insight into the learning process being taken, providing guidance for the learning material being studied and operational steps for exploring standard material more thoroughly (Good, et al., 2010). In the teaching materials, there are instructions and descriptions of the material. One of the efforts to improve the quality of education is through the procurement of quality subject matter (Hosler and Boomer, 2011; Lee, et al., 2010), and can be started from writing learning modules (Situmorang, et al., 2011). A good learning module must be able to present teaching materials in accordance with the demands of the curriculum, follow the development of science and technology (IPTEK), and be able to bridge learning so that the competencies that have been set can be achieved (Jippes, et al., 2010; Jungnickel, et al., 2009). Based on the opinion above, it can be stated that the function of teaching materials can be divided into three, namely the function of teaching materials in classical learning, individual learning, and group learning.

The Nature of Learning

The learning process is a communication process between educators and students, or between students. The communication process is carried out verbally (verbally) and can also be non-verbal, such 
as the use of computers in learning. The essence of learning is characterized by a series of communication activities. Elias (2011) explains that related to the problem of the learning process, several important questions arise, including "how effective is the course? Is it meeting the needs of the students? How can the needs of learners be better supported? What interactions are effective? How can they be further improved? ". According to Hergenhahn and Olson (2008) learning is "something that occurs as a result or result of experience, namely the occurrence of changes in behavior. Furthermore, according to Watkins, Carnell, Lodge, Wegner \& Whalley (2002) learning is “...reflective activity w hich enables the learner to fromaw upon previous experience to understand and evaluate the present, so as to shpe future action and formulate new knowledge".

According to Law no. 20 of 2003, the learning process is carried out so that students actively "... develop their potential to have religious spiritual strength, self-control, personality, intelligence, noble character, and skills needed by themselves, the nation's community and the state". Learning is measured by changes in behavior, in other words the results of learning must always be translated into observable behavior or actions. After undergoing the learning process, learners will be able to do something they could not do before they learned. The success of learning is determined by how the instructor learns. According to Ali (2008) teaching is "...the process of guiding learning activities, and teaching activities are only meaningful when there are learning activities by students/craftsmen". Therefore, it is very important for every instructor to understand as well as possible about the learning process of craftsmen. Learning is considered as a process of changing behavior as a result of experience and practice.

Wilson and Peterson (2006) explain learning is "active constructor of meaning, and focuses on behavior". Witherington (2013) argues that learning is "a change in personality that expresses itself as a new pattern of reactions in the form of skills, attitudes, habits, intelligence or an understanding". Hamalik (2009) reveals that learning is "...modification or strengthening behavior through experience". According to this understanding, learning is a process of an activity and not an outcome or goal. Learning is not just remembering, but more broadly than that, experiencing learning outcomes is not a mastery of the results of the exercise but a change in behavior.

Learning can occur if there is interaction between instructors and craftsmen and craftsmen and craftsmen. Regarding the definition of learning, many experts have expressed their opinions, including Slameto (2003) stating that, learning is a business process carried out by a person to obtain a new behavior change as a whole, as a result of his own experience in interaction with his environment ".

This opinion is almost the same as Sardinian (2003) which states "learning is a change in behavior or appearance, with a series of activities, for example by reading, observing, listening, imitating and so on. According to Sanjaya (2008) there are two streams of learning, namely the "behavioristic and cognitive" learning flow.

Sanjaya, (2008). Explaining according to the behavioristic school, learning is essentially the formation of associations between the impressions captured by the senses and the tendency to act or the relationship between stimulus and response (S-R). Learning is an effort that forms a stimulus and response relationship as much as possible. Learning theories that fall into the behavioristic group include "Connectionism; Classical conditioning; operant conditioning; systematic behavior; and contiguous conditioning". Furthermore, according to Kruse (2009) cognitive theory "focuses on how students make meaning of new information and experience". Revealed by Asia University (2010) the three big anchovies that influence cognitive theory are: Teaching materials

Teaching materials are all forms of materials used to assist teachers or instructors in carrying out teaching and learning activities in the classroom. The material in question can be in the form of written or unwritten material. Majid (2012) explains that with teaching materials, it allows students to learn a competency or basic competency in a coherent and systematic manner so that cumulatively they are able to master all competencies in a complete and integrated manner.

Prastowo (2013) states that teaching materials are a set of materials that are systematically arranged, whether written or not, so as to create an environment or atmosphere that allows students to 
DOI: https://doi.org/10.24036/icolp.v1i1.33

learn. There are also those who argue that teaching materials are information, tools and texts needed by teachers or instructors for planning and studying the implementation of learning. In line with this understanding, Panne (in Prastowo, 2013), defines teaching materials as learning materials or learning materials that are systematically arranged that are used by teachers and students in the learning process.

Based on some understanding of these teaching materials, it can be concluded that teaching materials are a set of subject matter or a set of tools and materials that are systematically arranged by the teacher and used in learning activities so as to create an environment or atmosphere that allows students to learn and can achieve predetermined goals.

\section{Classification of Teaching Materials}

Teaching materials include various types, such as textbooks, modules, worksheets, learning audio and so on. Experts have made several classifications for various kinds of teaching materials that have been used in learning activities. Even so, no one has been able to make a truly authentic and final classification, so that there are no weaknesses here and there. Prastowo (2013: 306), classifies teaching materials into the following four sections.

1. According to the form of teaching materials, they consist of: (a) printed materials; (b) listening teaching materials (audio) or audio programs; (c) visual and auditory teaching materials; 4) interactive teaching materials.

2. According to how the teaching materials work, they consist of: (a) non-projected teaching materials; 2) projected teaching materials; (b) audio teaching materials; (c) video teaching materials; (d) computer materials (media).

3. According to the nature of the teaching materials, they consist of: (a) print-based teaching materials; technology-based teaching materials; (b) teaching materials used for practice or projects; (c) teaching materials needed for human interaction purposes.

4. According to the substance of the teaching material, it consists of: (a) cognitive aspect material; (b) affective material and (c) psychomotor material.

Meanwhile Majid (2012:174) classifies the teaching materials used in the following learning (1) printed teaching materials, (2) listening teaching materials, (3) viewing teaching materials, (4) interactive teaching materials.

Printed teaching materials can be displayed in various forms (a) handouts (b) textbooks, (c) modules, (d) photos/pictures.

a. Handout

Handouts are usually taken from several libraries that are relevant to the material to be delivered. Handouts can be obtained in various ways, including by downloading from the internet or being inspired by several books and sources.

b. Textbooks

Books are written materials that present the knowledge/ ideas of the author. By the author, the contents of the book are obtained in various ways, for example: research results, observations, actualization of experiences, autobiographies, or works of fiction. A good book is a book that is written using good language and is easy to understand, presented in an attractive manner, accompanied by pictures and descriptions, the contents of the book also describe something that is in accordance with the idea of lu200blu200bthe writing.

c. Photos/Pictures

Pictures as story illustrations really support students' understanding in appreciating stories and developing students' imaginations in understanding the contents of the stories they read. In addition, the presence of pictures in learning to appreciate stories can be used as illustrations for students in understanding stories. Images that can be used as illustrations can be in the form of pictures of students communicating about the material being presented in the teaching materials. Based on several types of 
teaching materials, it can be stated that the teaching materials to be developed in this study for learning Indonesian courses at FKIP UPI Yptk Padang are teaching materials.

Functions and Benefits of Preparation of Teaching Materials

Teaching materials have a strategic function for the learning process that can help teachers and students in learning activities, so that teachers do not present too much material. In addition, teaching materials can partially replace the role of the teacher and support individual learning. This will have a positive impact on teachers, because some of their time can be devoted to guiding student learning. The positive impact for students, can reduce dependence on teachers and get used to independent learning. It also supports the principle of lifelong learning (long life education). There are two classifications of functions of teaching materials according to Prastowo, (2013: 299-301) as described below.

1) The function of teaching materials according to the parties who use the teaching materials. divided into two types, namely as follows. (a) the function of teaching materials for teachers, (b) the function of teaching materials for students. The function of teaching materials for teachers is as follows. (1) saving teacher time in teaching, (2) changing the teacher's role from a teacher to a facilitator, (3) improving the learning process to be more effective and interactive, (4) as a guide for educators in the learning process, (5) as a tool evaluation of learning outcomes. The function of teaching materials for students is as follows. (1) So that students can learn without having a teacher or other student friends. (2) So that students can learn whenever and wherever they want. (3) So that students can learn at their own pace. (4) So that students can learn according to the order of their own choosing. (5) Helping potential students to become independent students/students. (6) As a guide for students who will direct all their activities in the learning process.

2) The function of teaching materials according to the learning strategies carried out is divided into three types and can be described as follows. (a) the function of teaching materials in classical learning, (b) the function of teaching materials in individual learning, (c) the function of teaching materials in group learning. The function of teaching materials in classical learning, among others, are as follows. (1) as the only source of information as well as supervisors and controllers of the learning process for students, (2) as supporting materials for the learning process. The function of teaching materials in individual learning, among others, are as follows. (1) as the main media in the learning process, (2) as a tool used to organize and supervise the process of students in obtaining information, (3) as a support for other individual learning media. The function of teaching materials in group learning, among others, are as follows. (1) As an integrated material with the group learning process, by providing information about the background material, information about the roles of the people involved in group learning, as well as instructions on the group learning process itself. (2) As a supporting material for the main learning materials to increase students' learning motivation.

Based on the opinion above, it can be stated that the function of teaching materials can be divided into three, namely the function of teaching materials in classical learning, individual learning, and group learning. It can be stated that the proper function of classical learning in language learning is as a teaching material that is integrated with the learning strategy used, by providing information about the background material, information about learning, so that it is used as material to support the learning process that is held.

\section{Methods}

The development model used in this research is the ADDIE development model. The concept of ADDIE (analysis, design, development, implementation) Dick, Carey (2001:4) is used to describe a systematic approach. All elements of the model are related to each other starting from analysis, design, development, implementation and assessment. This ADDIE model can be described as below. 


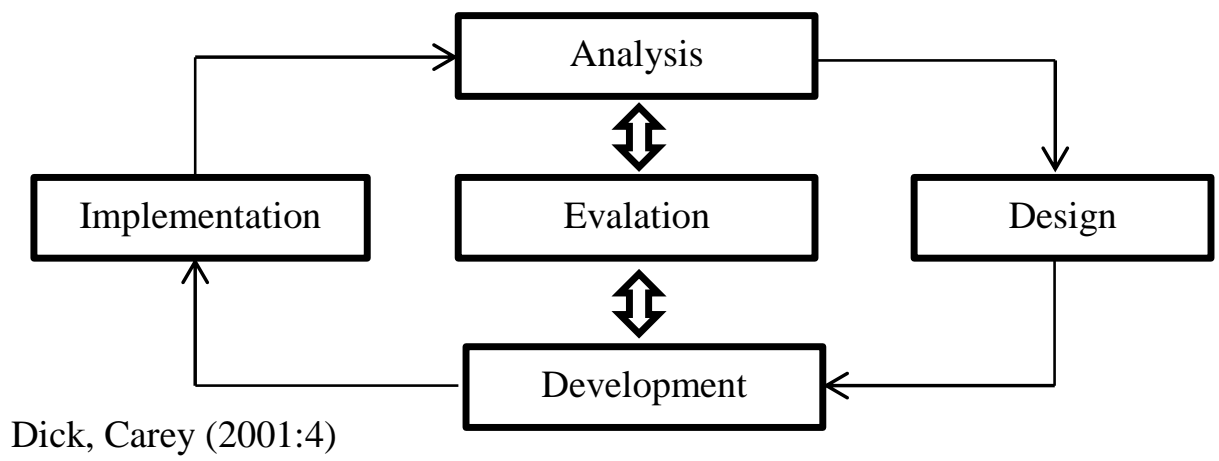

Figure 1. ADDIE Model Development Procedure

Tabel 1. Types, Data Forms and Data Analysis Techniques

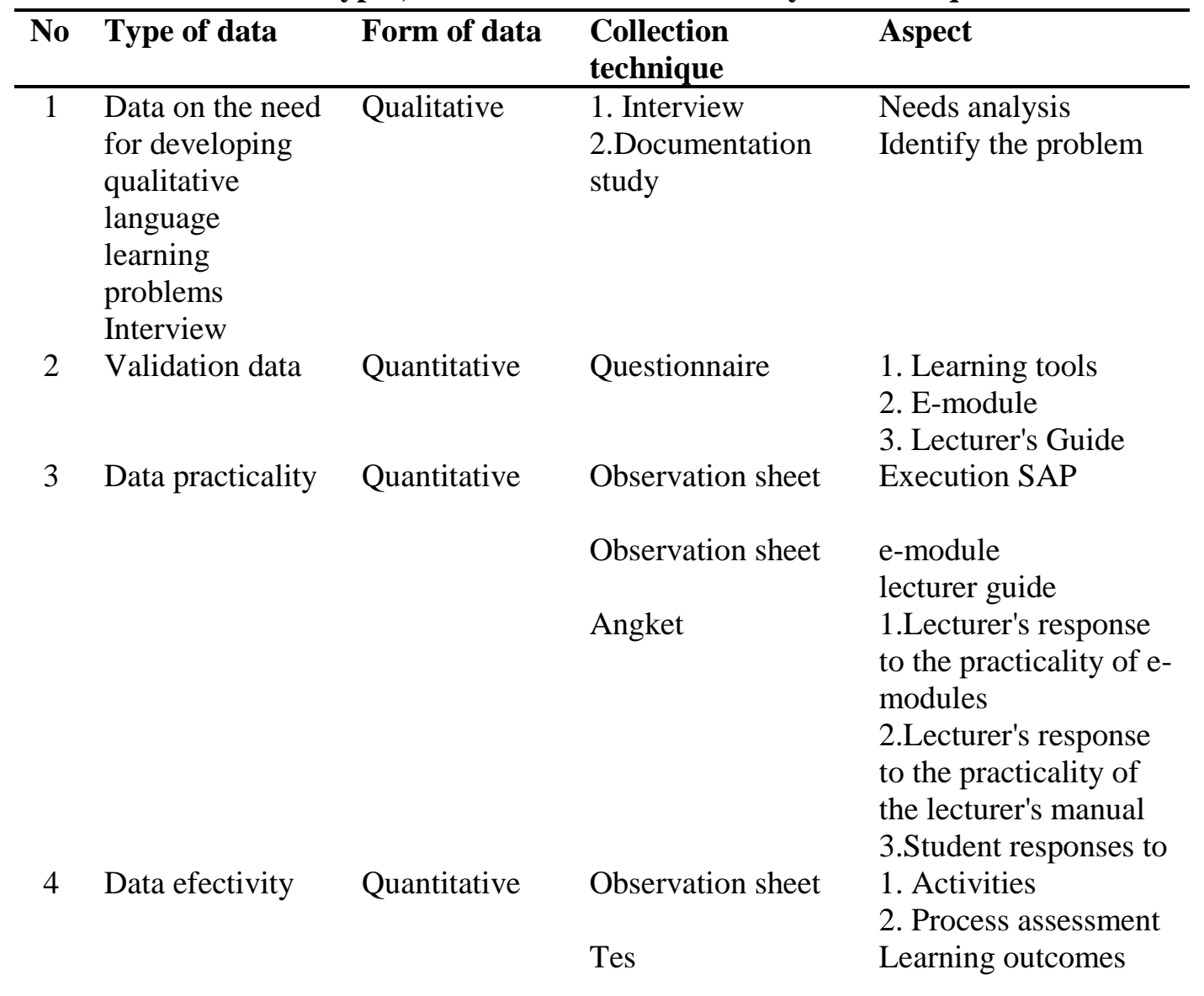

Based on the type of data and data collection techniques, there are several kinds of data collection instruments. These instruments include; 1) interview guide, 2) validation sheet, and 3) questionnaire. The use of each of these instruments is explained based on the required data as follows.

The assessment sheet in the form of a questionnaire was prepared using alternative answers/assessments using a Likers scale in the form of very good (SB), good (B), quite good (CB), not 
good $(\mathrm{KB})$ and not good $(\mathrm{TB})$. Each alternative answer is given a score of $\mathrm{SB}=5, \mathrm{~B}=4, \mathrm{CB}=3, \mathrm{~KB}=2$, and $\mathrm{TB}=1$.

The research method explains clearly how the research was conducted to enable readers to evaluate the work performed. State the research design used in the study. Describe precisely what you did, what and how experiments were run, what, how much, how often, where, when, and why equipment and materials were used. Define the population and the methods of sampling or participants were used in the study. Describe what, how and to whom the instruments were used in the study. Describe any approaches to ensure validity and reliability. Describe how the data were collected and analyzed. Describe statistical tests and the comparisons made. In analyzing needs, the researcher analyzes: a) learning problems, b) availability of training for lecturers, c) analysis of student interest in learning, d) analysis of the availability of learning resources for students. The needs analysis was carried out by researchers using observations, interviews with course lecturers and students taking Indonesian language courses. Finally, the researcher conducted a theory analysis related to development. The results of the analysis obtained are used for information and descriptions in designing this study.

\section{Result and Discussion}

Research results should Development research on teaching materials in Indonesian language courses as a source of independent learning for students at FKIP UPI Yptk. The results of development research conducted through a learning design with trial subjects conducted on students. The results of the development of textbooks were seen from the results of measuring the validity, practicality, and effectiveness of the implementation of learning using the teaching materials.

1. The validity developed in the study is classified as valid. This shows that the aspects contained in the textbook include; a) physical aspects, b) linguistic aspects, c) material aspects, d) presentation aspects, e) graphic aspects, f) cover aspects have been prepared completely according to student needs to be used in the learning process.

2. The practicality of teaching materials in Indonesian Language Courses is generally classified as a practical category. This is obtained from the results of observations in the learning class of teaching lecturers, observation sheets on the use of textbooks, lecturer responses, and student responses to practicality. This also provides an overview that can help in the implementation of the learning process.

3. Effectiveness can be known through student activities, assessment of the learning process using textbooks. In general, student activities have been carried out well, the assessment of student skill processes is also carried out very effectively, while the average value of student learning outcomes using textbooks is $68.11 \%$ with a high category, meaning that when the learning process takes place, student activities very good in understanding and using the developed textbook.

Results of the Design Phase (Design)

Teaching Materials

Teaching materials design stage includes validation and is adjusted to the general instructional objectives and specific instructional objectives then presented in the multimedia e-module learning. Learning with multimedia e-modules is an independent learning approach that focuses on the instructional objectives of the study materials that students learn at a certain time according to their potential and conditions. The self-study system is a way of learning that focuses more on the role of student autonomy. Independent learning is the behavior of students in realizing their desires or desires in real terms by not depending on others. In this case, the student is able to do his own learning, can determine effective ways of learning, is able to carry out learning tasks well, and is able to do.

Development Stage Results (Develop)

In this stage of development, researchers develop research products with the following steps. 
Based on the picture above, the process of developing teaching materials in Indonesian Language courses requires a lecturer's manual and learning model books using teaching materials. The development concept is described as follows.

In the early stages of development, several activities were carried out, including: 1) conducting FGDs discussing the material content of the three finished products and gathering input/suggestions about products, 2) revising products to improve the three products (guide books, model books and e-books). multimedia module) based on input/suggestions from the FGD, 3) validating the three products (guide books, model books and multimedia e-modules) through validation of filling in the validation instrument by experts, 4) revising the product if it needs to be improved, 5) conducting trials products and 6) product implementation on a wide scale.

Student Response to the Practicality of the teaching materials

Assessment of student responses was carried out to find out students' opinions on the level of practicality. The assessment sheet is filled out by students at the end of the one-to-one evaluation. The results of the practicality sheet after using the multimedia e-Modul can be seen in the following table.

Table 2. Practical Teaching Materials

\begin{tabular}{|llll|}
\hline Mahasiswa & Nilai & Rata-rata & Kategori \\
\hline Riri Putri & 61 & 87.57 & Sangat praktis \\
\hline
\end{tabular}

Student responses to the practicality of the teaching materials in the one-to-one evaluation trial showed that the percentage of student assessment of the multimedia e-module was in the very practical category, namely 88.57 . Thus, it can be concluded that the practicality of the teaching materials based on the one-to-one evaluation of student response sheets is categorized as very practical and attractive to students.

\section{Effectiveness Test Results}

Student activity during the activity was observed using the student activity observation instrument. The student activities observed included a) visual activities, b) listening, c) oral activities, d) motor activities, e) writing activities. Student activity in the one-to-one test can be concluded that student activity in the one-to-one evaluation test for each meeting has an average of $94.40 \%$ in the very good category. From the results of the analysis, it can be concluded that meeting 1 to meeting 5 of student activities as a whole has been carried out very well.

Based on the description above, the developed Textbooks can help in increasing student activities. In addition, lecturers who support courses feel facilitated by the teaching materials being developed. Multimedia e-modules provide motivation and attraction for students to learn which is indicated by increasing student activities during the learning process. Thus, from student activities, the Textbooks has been effectively applied in learning.

\section{Assessment of Teaching Materials Learning Skills}

Process Assessment

The development of Textbooks in Indonesian language courses by adopting the ADDIE model has been successfully implemented. The multimedia e-module has been tested on FKIP UPI YPTK Padang students in two ways, namely; 1) a one-to-one evaluation trial, namely a trial involving one student, 2) a small group evaluation trial, namely a trial in the form of small groups, while in the implementation phase it was carried out on students who took Indonesian language courses with a total number of students 40 students. 
DOI: https://doi.org/10.24036/icolp.v1i1.33

The description of the results of the development research that has been carried out is explained in relation to the validity, practicality, and effectiveness of the developed teaching materials. For more details will be described below.

Validitas

The multimedia e-module that has been developed is said to be valid if it meets certain criteria. Plomp (2007:127) a product is said to be valid if it reflects the soul of knowledge (state of the ort knowledge). This is what is called content validation. Furthermore, the product components must be consistent with one another (construct validity). The validation carried out on the Textbooks emphasizes content and constructs. In this study, validation is further detailed into product validation which is carried out on content, language, presentation, and graphics.

\section{Conclusion}

This research is a development research in Indonesian language courses for UPI YPTK Padang. This research was conducted because there is no teaching materials as an independent learning resource for FKIP UPI Yptk Padang students. The results of development research carried out through a learning design with trial subjects were carried out on FKIP UPI YPTK Padang students. The results of teaching materials development are seen from the results of measuring the validity, practicality, and effectiveness of the implementation of learning using teaching materials.

1. Validity of Indonesian teaching materials Courses

The validity of the teaching materials developed in this study is classified as very valid. This shows that the aspects that exist in the e-module include; a) physical aspects, b) linguistic aspects, c) material aspects, d) presentation aspects, e) graphic aspects, f) cover aspects have been prepared completely according to student needs to be used in the learning process.

2. Practicality of Teaching Materials in Indonesian Language Courses

The practicality of multimedia e-modules is generally classified as a very practical category. This is obtained from the results of observations on the implementation of learning to teaching lecturers, observation sheets on the use of teaching materials, lecturers' responses, and student responses to the practicality of teaching materials can assist in the implementation of the learning process.

3. The Effectiveness of Teaching Materials in Indonesian Language Courses

The effectiveness of multimedia e-modules can be known through student activities, assessment of the learning process using interactive teaching materials. In general, student activities have been carried out well, the assessment of student skill processes is also carried out very effectively, while the average value of student learning outcomes using e-modules is $76.14 \%$ with a high category, meaning that when the learning process takes place, participant activities students are very good at understanding and using the teaching materials.

4. ADDIE Research Development Model (Analysis, Design, Development, Implementation, Evaluation) The concept of the ADDIE model is used to describe a systematic approach. All elements of the model have a relationship with each other starting from Analysis, Design, Development, Implementation, Evaluation on the ADDIE research development model is the first step in helping researchers analyze problems that occur in the field.

This development research has produced e-modules in Indonesian courses for UPI YPTK Padang. Basically, this research has also provided an overview and input for students because it can increase knowledge for students, especially students who take Indonesian language courses.

\section{References}

Ary, D., Jacobs, L. C., Razavieh, A. (2006). Introduction to reasearch in education.Seventh Edition. Belmont. CA, USA: Thomson Higher Education 10 Devis Drive. 
Bauman, J.F, dkk. (1992). "Effect of think aloud instruction on elementary students comprehension monitoring abilities." Journal of Reading Behavior, Vol.24, No.2 Februari 1992.

Dick and Carey (1996). The systematic dessign of instuction. New York :Harper Collins Publishers.

Hosler, J dan Boomer, K.B., (2011). Are comic books an effective way to engage nonmajors in learning and appreciating science. CBE-Life Sciences Education 10: 309-317.

Kruse. (2009). What is employee engagement. Forbes Leadership.

Majid, Abdul. 2012. Perencanaan pembelajaran. Bandung: Rosda Karya.

Plomp, T. dan Nieveen, N. (Eds). (2007). An Introduction to educational design research. Enschede: Netherlands Institute for Curriculum Development (SLO).

Prastowo, Andi. (2013). Panduan kreatif membuat bahan ajar inovatif. Yogyakarta: Diva Press.

Putra, Nusa. 2012. Research and development, penelitian dan pengembangan: Suatu pengantar. Jakarta: Raja Grafindo Persada. 